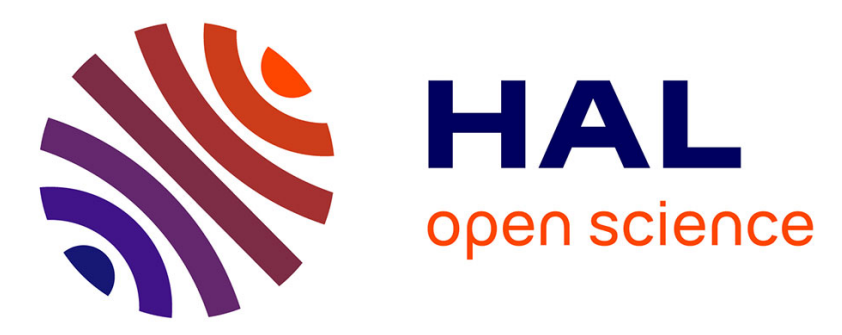

\title{
Particle Impact Behavior of Silicon-Nitride Ceramic at Elevated Temperature
}

\author{
H. Yoshida, Y. Hara, T. Shimamori
}

\section{To cite this version:}

H. Yoshida, Y. Hara, T. Shimamori. Particle Impact Behavior of Silicon-Nitride Ceramic at Elevated Temperature. Journal de Physique IV Proceedings, 1997, 07 (C3), pp.C3-1057-C3-1062. 10.1051/jp4:19973178 . jpa-00255473

\section{HAL Id: jpa-00255473 https://hal.science/jpa-00255473}

Submitted on 1 Jan 1997

HAL is a multi-disciplinary open access archive for the deposit and dissemination of scientific research documents, whether they are published or not. The documents may come from teaching and research institutions in France or abroad, or from public or private research centers.
L'archive ouverte pluridisciplinaire HAL, est destinée au dépôt et à la diffusion de documents scientifiques de niveau recherche, publiés ou non, émanant des établissements d'enseignement et de recherche français ou étrangers, des laboratoires publics ou privés. 
J. PHYS IV FRANCE 7 (1997)

Colloque C3, Supplément au Journal de Physique III d'août 1997

\title{
Particle Impact Behavior of Silicon-Nitride Ceramic at Elevated Temperature
}

\author{
H. Yoshida, Y. Hara* and T. Shimamori* \\ Mechanical Engineering Laboratory, AIST, MITI, Namiki 1-2, Tsukuba 305, Japan \\ * NGK Spark Plug CO., LTD., R\&D center, 2808 Iwasaki, Komaki-shi, Aichi 485, Japan
}

\begin{abstract}
By using a novel particle launch system, the impact tests of silicon nitride ceramic have been carried out. Particle of $1 \mathrm{~mm}$ dia. and $4 \mathrm{mg}$ weight was impacted on the ceramic specimen at velocities up to $1000 \mathrm{~m} \mathrm{~s} \mathrm{~s}^{-1}$ under the temperatures up to $1350^{\circ} \mathrm{C}$ and tensile loads up to $100 \mathrm{MPa}$. The results show a significant influence of the temperature on the impact fracture behavior. At the room temperature, a map of fracture modes in terms of material bending strength and thickness is shown. In the last, non-dimensional parameter required to estimate critical velocity for strength degradation is obtained.
\end{abstract}

Résumé. Des essais d'impact de céramique en nitrure de silicium ont êté réalisés à l'aide d'un nouveau système de lancement. Les échantillons de céramique ont étés impactés à l'aide de particules de $1 \mathrm{~mm}$ de diamètre et $4 \mathrm{mg}$ de masse jusqu'a des vitesses de $1000 \mathrm{~ms}^{-1}$, des températures de $1350^{\circ} \mathrm{C}$ et des chargements en tension de $100 \mathrm{MPa}$. Les résultats montrent une influence significative de la température sur le comportement de la rupture sous impact. Pour la température ambiante, une cartographic des modes de rupture en fonction de la résistance du matériau en flexion et de l'épaisseur est indiquée ainsi qu'un parametre sans dimension estimant la vitesse critique de l'endommagement.

\section{INTRODUCTION}

Recently, because of high heat tolerance and several advantages in mechanical properties, ceramic materials have been utilized as components of thermal engines, such as gas turbines [1]. In spite of those promising properties, however, the brittle nature of the material sometimes causes, so called, foreign object damages (FODs) by impacts [2], which has not been so sever in the ordinary metal turbines. In the actual turbines the ceramic elements are expected to be utilized at elevated temperatures higher than $1000^{\circ} \mathrm{C}$. Therefore, it is important to understand the impact behavior of the ceramic materials at elevated temperatures as well as that of the room temperature. So far an effort has been made for developing particle impact technique under elevated temperatures [3].

In this paper, the particle impact behavior of monolithic silicon-nitride ceramic $\left(\mathrm{Si}_{3} \mathrm{~N}_{4}\right)$ is investigated experimentally both under the room and the elevated temperatures. The silicon-nitride is one of the candidate materials for the $300 \mathrm{~kW}$ class gas turbines under developing [1]. The impact experiment was carried out by using a novel impact device developed at MEL [3]. In the present impact system, we can apply tensile loads to the specimen, as well as controlling the temperature condition. The tensile load is considered to simulate centrifugal forces in the turbomachinery.

\section{EXPERIMENTAL DETAILS}

A schematic diagram of the impact system is shown in Fig.1. The system consists of the electrothermal (ET) gun, furnace, and tensile load applying unit. Samarium-cobalt $\left(\mathrm{Sm}_{2} \mathrm{Co}_{17}\right)$ rare earth magnetic sphere of $1 \mathrm{~mm}$ diameter and $4 \mathrm{mg}$ weight was used as an impact particle. The reason of using the magnetic particle is to facilitate the direct measurement of the particle velocity by the magneto-flyer technique [4]. The available impact velocity, temperature and tensile load range, respectively, up to $1000 \mathrm{~m} \mathrm{~s}^{-1}, 1400^{\circ} \mathrm{C}$ and $19600 \mathrm{~N}$. The more details are given in Ref. [3].

The mechanical properties of the samarium-cobalt particle (manufactured by Shin-Etsu Chemical Co., Ltd.) are: density $=8.4 \mathrm{~g} \mathrm{~cm}^{-3}$, bending strength $=117.6 \mathrm{MPa}$, Young's modulus $=151 \mathrm{GPa}$, Vickers hardness $=5.39 \mathrm{GPa}$, Poisson's ratio $=0.17$ (or 0.26 , reference data). Those of the silicon nitride ceramics employed here are listed in Table 1 . In this experiments specimens of two different geometries were used: one was rectangular type (Fig.1(b)) and the other one was disk type (Fig. 1(c)). The surface of the rectangular specimen was finished with a grade 400 grit diamond wheel and that of 
(a)

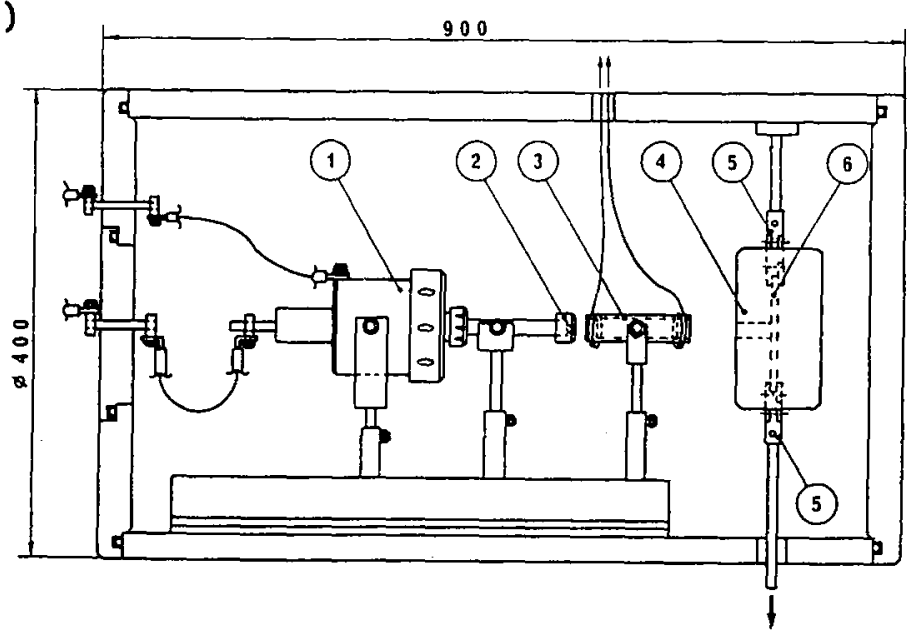

(b)

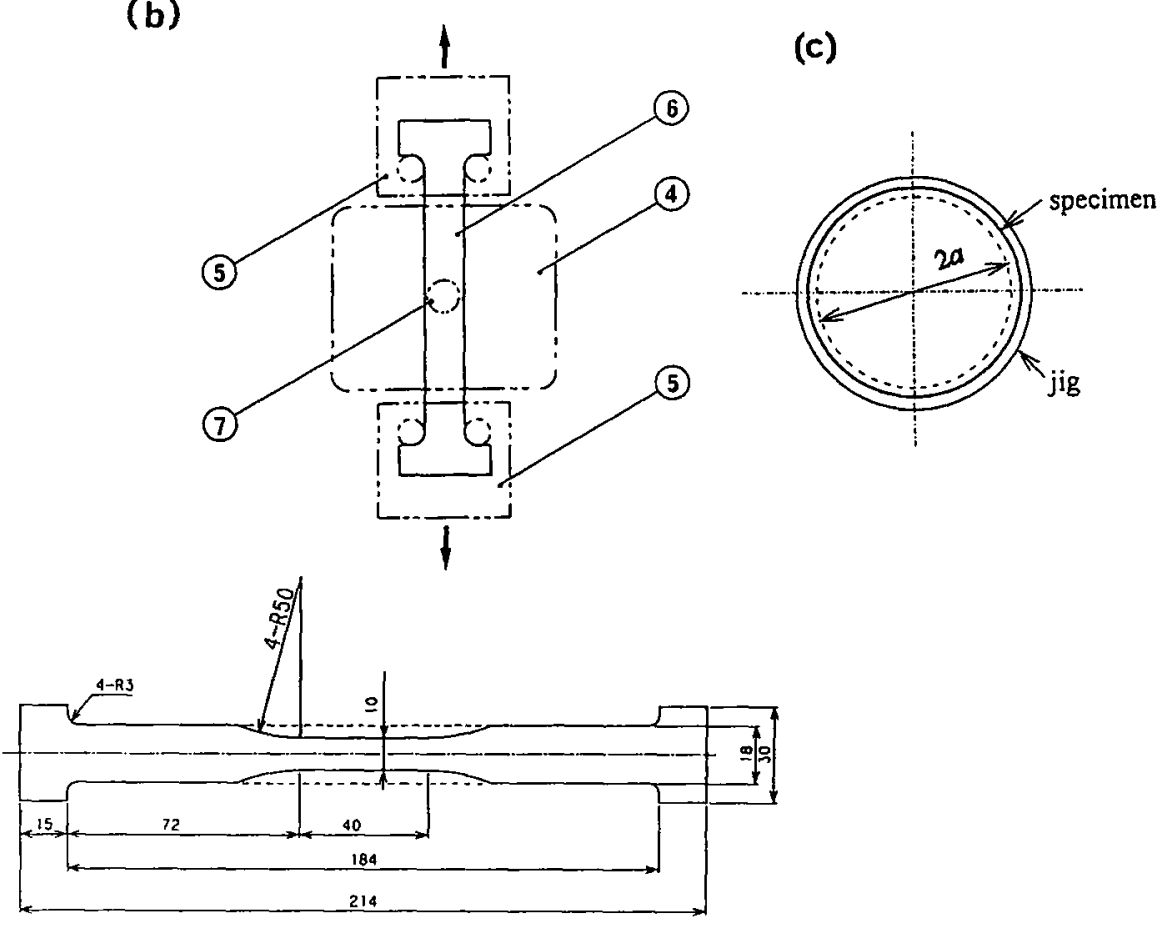

Fig. 1(a) Experimental set-up: 1, electrothermal (ET) gun; 2, sabot stopper; 3, particle velocity detector (induction coils); 4, furnace; 5 , universal joint for tensile load; 6 , ceramic specimen (in millimeters). (b) Rectangular specimen: 1-6, the same as indicated in (a); 7, aperture for impact particle. The precise geometry is given in the bottom, where dotted line refers to SN252 specimen (in millimeters). (c) Disc specimen. In the present case, diameter $2 a=30 \mathrm{~mm}$. 
the disk specimen were lapped up to mean roughness $R \mathrm{a}=0.04 \mu \mathrm{m}$ and maximum roughness $R \max =$ $0.4 \mu \mathrm{m}$, where the roughness measurement was made according to the Japanese Industrial Standard, JIS B0601.

\section{RESULTS AND DISCUSSION}

\subsection{Impact under elevated temperature with tensile load}

The impact tests were carried out by using the rectangular specimens of SN252 (18 mm width, dotted line in the bottom of Fig. 1(b)) and EC-152 (10 mm width, solid line in the same figure) with $3 \mathrm{~mm}$ thick. The impact results are listed in Table 2 . The temperature was monitored at the middle point of the specimen. "Total rupture" and "No rupture" in this table mean, respectively, the case where the specimen was broken into two pieces after the particle impact and the case where only the impact trace was left without total fracture. The results of Impact 1 to 4 are reproduced from Ref. [5], in which the particle impact tests under the elevated temperature and tensile load were reported for the first time. From the results of SN252 specimen at elevated temperatures with $64 \mathrm{MPa}$ tensile stress, the critical impact velocity for fracture seems to lie between 400 and $760 \mathrm{~m} \mathrm{~s}^{-1}$. On the other hand, at room temperature with the same $64 \mathrm{MPa}$ tensile stress the critical velocity seems to be higher than $770 \mathrm{~m} \mathrm{~s}^{-1}$ (impact 3) [5]. Those results of SN252 specimens indicate a significant effect of the temperature on the impact behavior of the material, i.e. appreciable strength degradation at the elevated temperature.

For the results of EC-152 specimens (Impact 5 to 8), we find that : at elevated temperature with 100 $\mathrm{MPa}$ tensile stress, the critical impact velocity for fracture seems to be lower than $890 \mathrm{~m} \mathrm{~s}^{-1}$ (Impact 5), while at the room temperature with the same $100 \mathrm{MPa}$ tensile stress, the critical velocity seems to be higher than $870 \mathrm{~m} \mathrm{~s}^{-1}$ (Impact 8). This result may be also related to the significant temperature effect on the impact fracture behavior like the previous case of SN252 specimen. At elevated temperature without tensile stress, the critical velocity seems to be higher than $590 \mathrm{~m} \mathrm{~s}^{-1}$ (Impact 6). At present, since the results are very limited, we have only obtained a rough image of impact behavior at elevated temperatures with tensile stresses. In order to attain much precise understanding, further effort should be made in future.

\subsection{Bending and Herzian cracks induced by the impact}

In the sections 3.2 and 3.3, the disk specimens with $40 \mathrm{~mm}$ diameter (Fig. 1(c)) were used. The impact experiments were carried out at the room temperature. Figure 2 shows relationship between the impact velocity, $V$, and a parameter, $\sigma^{5 / 6} t^{5 / 3}$, where $\sigma$ is the four point bending strength and $t$ is the thickness of the specimen. This material parameter was introduced based on the bending theory of thin plate [6] and to see roughly the general trend of the critical impact velocity for bending cracks $[5,7]$. In this figure the cases where the visible cracks appear on the rear surface of the specimen after impact are shown by closed symbols, $\square, \mathbf{A}$, (damaged cases) and those without any cracks by open symbols, $\bigcirc, \square, \triangle$, (undamaged cases). The solid line indicates the empirical relationship of $V=0.85 \sigma^{5 / 6} t^{5 / 3}$. As can be seen in this figure, the empirical relationship well defines the boundary of crack initiation for $t \leqq 1.5 \mathrm{~mm}$. Above $1.5 \mathrm{~mm}$ thick, the critical impact velocity seems to reach a plateau. In this thick region, thin plate theory scarcely describe the impact crack behavior for the bending mode.

In the separate experiments, it was found that the critical velocity for the ring crack initiation was about $400 \mathrm{~m} \mathrm{~s}^{-1}$ regarding the present materials (EC-152, ST-1 and ST-2). Above this velocity, the ring cracks tend to develop the well-known Hertzian cone cracks. Once the cone cracks appear, significant strength degradation of the material occurs [8]. Putting the result of the ring cracks together with those of the bending cracks discussed above, we can draw a rough image of a map of fracture modes in terms of material bending strength and thickness as shown in Fig. 3.

\subsection{Impact material parameter, $\phi_{1}$.}

One of the subjects we want to know through the series of the present impact experiment is the critical impact velocity for strength degradation of the material. According to Wiederhorn and Lawn [8], the critical velocity for Hertzian cracks, $V_{\mathrm{H}}$, which provoke the significant strength degradation, is expressed as:

$$
V_{\mathrm{H}}=\left(48 / 125 \pi^{3}\right)^{1 / 6}(k / E)^{7 / 6} \mathrm{Kc}^{5 / 3} / \rho^{1 / 2} r^{5 / 6} \phi_{1}^{* 5 / 6},
$$

where $\rho$ and $r$ are, respectively, the density and the radius of the particle, $E$ is the Young's modulus, $K \mathrm{c}$ 


\begin{tabular}{|c|c|c|}
\hline EC-152 & ST-1 & ST-2 \\
\hline$O$ & $\square$ & $\Delta$ \\
\hline 0 & 畻 & $\Delta$ \\
\hline
\end{tabular}

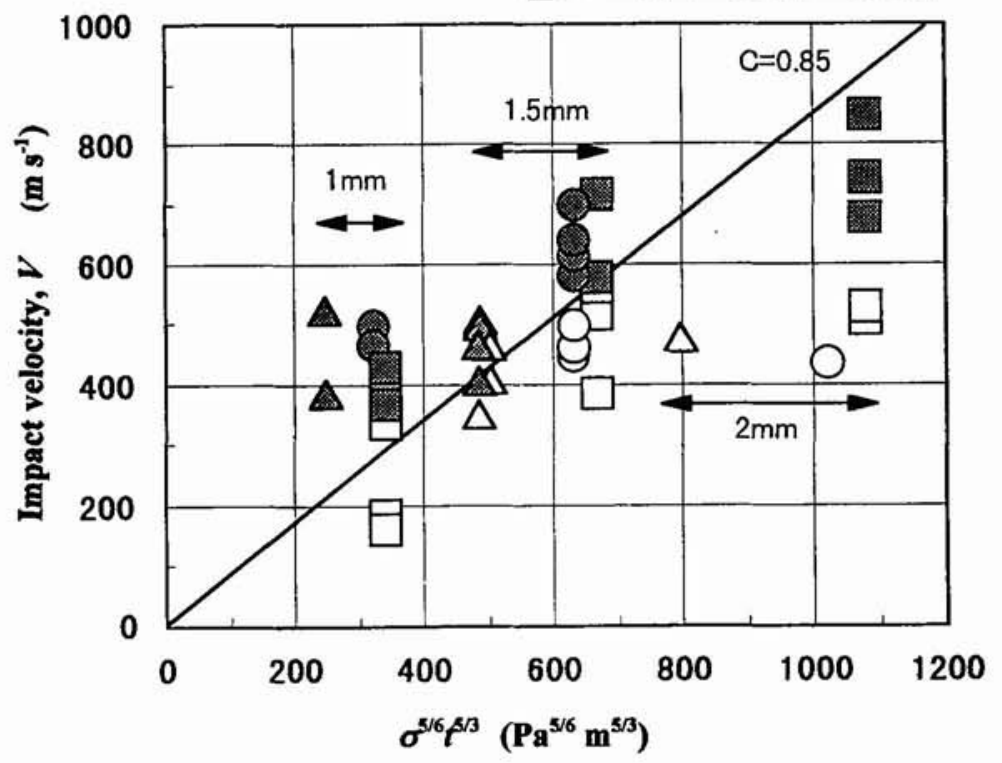

Fig.2 Critical impact velocity as a function of $\sigma^{3 / 6} t^{5 / 3}$. For symbols see text.

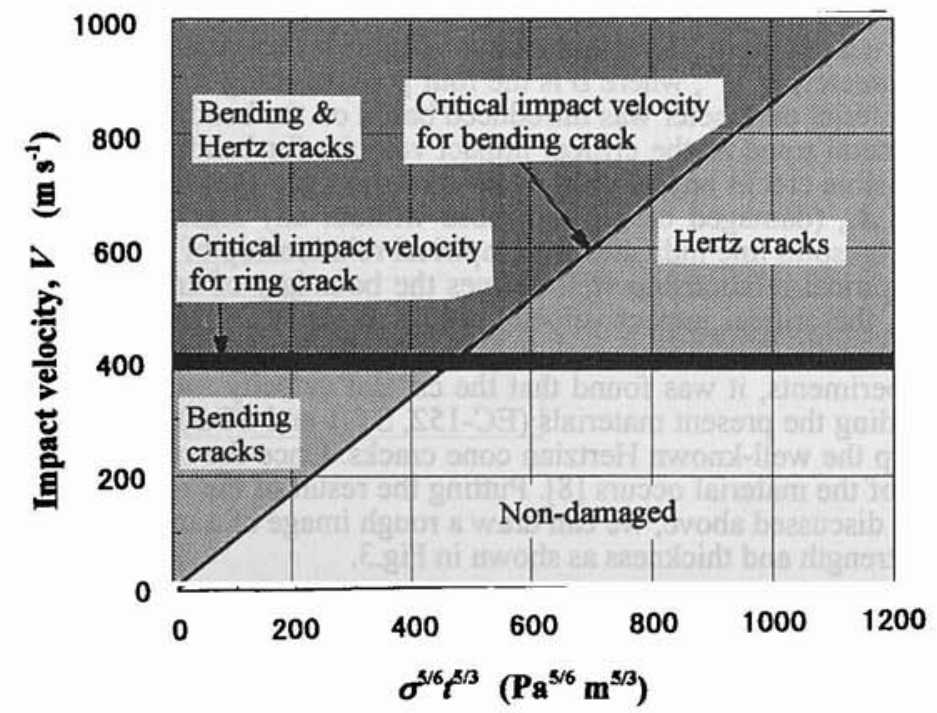

Fig.3 Map of impact fracture modes. 
is the fracture toughness of the target material, $k=(9 / 16)\left[\left(1-v^{2}\right)+\left(1-\nu^{2}\right) E / E\right]$, where the primes refer to the particle, and $\phi_{1}^{*}$ is a material parameter, which is given as a function of Poisson's ratio of the target material [8] and is discussed much precisely in Ref. [9]. Substituting material constants and $V_{\mathrm{H}}$ obtained experimentally, we can estimate the parameter $\phi_{1}{ }^{\circ}$ as shown in Table 3 , where we assume the critical velocity for the cone cracks is nearly equal to that for the ring cracks, i.e. $V_{\mathrm{H}}=400 \mathrm{~m} \mathrm{~s}^{-1}$. This assumption is not considered to be so unreal. For reference, the values of $\phi_{1}^{*}$ for $V_{\mathrm{H}}=500 \mathrm{~m} \mathrm{~s}^{-1}$ are also added in this table. In Ref. [8] $\phi_{1}{ }^{*}$ is given as $(1.6 \pm 0.2) \times 10^{-5}$ for $v=0.25$ (soda-lime glass). The present values of $\phi_{1}{ }^{*}$ in Table 3 seem to be reasonable for the present range of $v$ for EC-152, ST-1 and ST-2.

Finally, we can say that, for the silicon-nitride ceramic used here, a rough estimation of the critical impact velocity for strength degradation seems to be possible by using the known material properties and the non-dimensional parameter $\phi_{1}{ }^{*}$.

\section{References}

[1] Murayama T., Nagata K., Abe H., and Ogiyama H., "Current status of $300 \mathrm{~kW}$ industrial gas turbine - R \& D in Japan", ASME paper, 95-GT-445(1995)

[2] Song J., Cuccio J., Kington H., "Impact design methods for ceramic components in gas turbine engines", ASME paper, 91-GT-115(1991).

[3] Yoshida H., Hoshi Y., Uematsu K., and Kitazawa Y., "A single, small particle launch by electrothermal gun and microsabot", Rev. Sci. Instrum., Vol.68, No.1, (1997), pp.178-183.

[4] Kondo K., Sawaoka A., and Saito S., "Magnetoflyer method for measuring gas-gun projectile velocities", Rev. Sci. Instrum., Vol.48, No.12, (1977), pp.1581-1582.

[5] Yoshida H., Kano S., Hasegawa Y., Shimamori T., and Yoshida M., "Particle impact phenomena of silicon nitride ceramic", Philos. Mag., Vol.74, No.5(1996), pp.1287-1297.

[6] Shetty D.K., Rosenfield A.R., McGuire P., Bansal G.K., and Duckworth W.H., "Biaxial flexture tests for ceramics", Ceramic Bulletin, Vol.59, No.12, pp.1193-1197(1980).

[7] Hara Y., Makino K., Mizuno K., Shimamori T., and Yoshida H., "Particle impact tests of ceramic gas turbine materials at room temperature", ASME paper, 96-GT-504(1996).

[8] Wiederhorn S.M. and Lawn B., "Strength degradation of glass resulting from impact with spheres", J. Am. Ceram. Soc., Vol.60, No.9-10(1977), pp.451-458.

[9] Lawn B. and Wilshaw R., "Indentation fracture: principles and applications", J. Mater. Sci., Vol.10 (1975), pp.1049-1081. 
Table 1. Properties of silicon nitride ceramics employed here

\begin{tabular}{|c|c|c|c|c|}
\hline Property(unit) & SN252 & EC-152 & ST-1 & ST-2 \\
\hline $\operatorname{Density}\left(\mathrm{g} \mathrm{cm}^{-3}\right)$ & 3.4 & 3.26 & 3.37 & 3.42 \\
\hline Bending strength(MPa) & 615 & 1020 & 1090 & 760 \\
\hline Fracture toughness(MPam $\left.{ }^{1 / 2}\right)$ & 6.8 & 6.0 & 5.6 & 5.0 \\
\hline Young's modulus(GPa) & 309 & 318 & 317 & 320 \\
\hline Vickers hardness(GPa) & 13.7 & 14.7 & 16.7 & 14.2 \\
\hline Poisson's ratio & 0.28 & 0.26 & 0.28 & 0.27 \\
\hline
\end{tabular}

Table 2. Impact results of rectangular specimens

\begin{tabular}{cclcl}
\hline Test number & $\begin{array}{c}\text { Impact velocity } \\
\left(\mathrm{m} \mathrm{s}^{-1}\right)\end{array}$ & $\begin{array}{c}\text { Temperature } \\
\left({ }^{\circ} \mathrm{C}\right)\end{array}$ & $\begin{array}{c}\text { Tensile stress } \\
(\mathrm{MPa})\end{array}$ & Note \\
\hline Impact 1 & 763 & 1365 & 64 & $\mathrm{~T}$ \\
Impact 2 & 403 & 1365 & 64 & $\mathrm{~N}$ \\
Impact 3 & 775 & Room temp. & 64 & $\mathrm{~N}$ \\
Impact 4 & 684 & Room temp. & 0 & $\mathrm{~N}$ \\
Impact 5* & 885 & 1000 & 100 & $\mathrm{~T}$ \\
Impact 6* & 595 & 1000 & 0 & $\mathrm{~N}$ \\
Impact 7* & 639 & Room temp. & 100 & $\mathrm{~N}$ \\
Impact 8* & 873 & Room temp. & 100 & $\mathrm{~N}$ \\
\hline
\end{tabular}

(T:Total rupture, N:No rupture, ${ }^{*}$ : EC-152, others: SN252)

Table 3 Non-dimensional parameter, $\phi_{1}^{*}$.

\begin{tabular}{llll}
\hline & EC- 152 & ST-1 & ST-2 \\
\hline A & $1.62 \times 10^{-5}$ & $1.42 \times 10^{-5}$ & $1.12 \times 10^{-5}$ \\
B & $1.56 \times 10^{-5}$ & $1.35 \times 10^{-5}$ & $1.08 \times 10^{-5}$ \\
C & $1.24 \times 10^{-5}$ & $1.07 \times 10^{-5}$ & $8.55 \times 10^{-6}$ \\
D & $1.19 \times 10^{-5}$ & $1.03 \times 10^{-5}$ & $8.23 \times 10^{-6}$ \\
\hline
\end{tabular}

(A: $v=0.17$ and $V_{\mathrm{H}}=400 \mathrm{~m} \mathrm{~s}^{-1}, \overline{\mathrm{B}}: \nu=0.26$ and $V_{\mathrm{H}}=400 \mathrm{~m} \mathrm{~s}^{-1}, \mathrm{C}: \nu=0.17$ and $V_{\mathrm{H}}=500 \mathrm{~m} \mathrm{~s}^{-1}, \mathrm{D}: v^{2}=0.26$ and $V_{\mathrm{H}}=500 \mathrm{~m} \mathrm{~s}^{-1}$ ) 